\title{
Program One Week One Story Berbasis Keislaman sebagai Bekal Keterampilan Abad 21 pada Anak Usia Dini
}

\author{
Candra Wijaya $^{1 凶}{ }^{\bowtie}$, Rahmat Rifai Lubis $^{2}$, Haidir $^{3}$, Suswanto $^{4}$, Imron Bima Saputra $^{5}$ \\ Manajemen Pendidikan Islam, Universitas Islam Negeri Sumatera Utara Medan(1) \\ Pendidikan Agama Islam, Sekolah Tinggi Agama Islam Sumatera Medan(2) \\ Akuntansi, Universitas Muslim Nusantara Al-Washliyah Medan(3) \\ Pendidikan Agama Islam, Sekolah Tinggi Ilmu Tarbiyah Al Hikmah Tebing Tinggi(4) \\ Pendidikan Islam, Universitas Islam Negeri Sumatera Utara Medan(5) \\ DOI: $\underline{10.31004 / o b s e s i . v 5 i 2.917}$
}

\begin{abstract}
Abstrak
Penelitian ini bertujuan menganalisis program one week one story berbasis keislaman untuk mengatasi problematika kemampuan bahasa dan sosial AUD di TK Rusyda Medan. Pendekatan yang digunakan ialah pendekatan kualitatif dengan metode deskriptif. Pengumpulan data melalui teknik wawancara mendalam dengan panduan instrumen terstruktur, observasi dan kajian dokumen. Selanjutnya data dianalisa dengan teknik reduksi data, penyajian data, dan penarikan kesimpulan. Uji keabsahan data menggunakan teknik trianggulasi sumber dan metode. Hasil penelitian menunjukkan bahwa problematika kemampuan bahasa dan sosial AUD bersumber dari dalam diri anak (internal) dan luar diri anak (eksternal). Untuk mengatasinya diterapkan program one week one story berbasis keislaman. Penerapan program ini dilakukan dengan memberikan kesempatan kepada anak untuk menceritakan pengalaman selama liburan akhir pekan terutama cerita dengan konten keislaman seperti pengalaman Ibadah, silaturrahim, membaca Al-Qur'an, dan ta'awun. Dalam penerapan program tersebut kendala yang dihadapi ialah rasio guru dan siswa tidak sebanding dan kurangnya kerjasama guru dan orang tua.
\end{abstract}

Kata Kunci: one week one story; nilai-nilai keislaman; keterampilan abad 21

\begin{abstract}
This study aims to analyze the Islamic-based one week one story program to overcome the problems of language and social skills in AUD at TK Rusyda Medan. The approach used is a qualitative approach with descriptive methods. Collecting data through in-depth interview techniques with structured instrument guides, observation and document review. Furthermore, the data were analyzed using data reduction techniques, data presentation, and drawing conclusions. The data validity test used source and method triangulation techniques. The results showed that the problems of language and social skills in AUD originated from within the child (internal) and outside the child (external). To overcome this, an Islamic-based one week one story program was implemented. The implementation of this program is carried out by providing opportunities for children to share experiences during weekend holidays, especially stories with Islamic content such as experiences of worship, silaturrahim, reading the AlQur'an, and ta'awun. In implementing the program, the obstacles faced are the ratio of teachers to students is not comparable and the lack of cooperation between teachers and parents.
\end{abstract}

Keywords: one week one story; islamic values; 21st century skills

Copyright (c) 2020 Candra Wijaya, Rahmat Rifai Lubis, Haidir, Suswanto, Imron Bima Saputra

$\triangle$ Corresponding author:

Email Address: candrawijaya@uinsu.ac.id (Medan-Sumatera Utara, Indonesia)

Received 26 November 2020, Accepted 6 December 2020, Published 8 December 2020

1544 | Jurnal Obsesi: Jurnal Pendidikan Anak Usia Dini, 5(2), 2021 


\section{PENDAHULUAN}

Bahasa memiliki peran yang sangat urgen dalam kehidupan manusia, sebab dengannya manusia dapat berkomunikasi, menyampaikan maksud, gagasan, ide, dan saran kepada orang lain. (Salnita et.al., 2019). Tanpa adanya bahasa, mungkin akan sangat sulit rasanya untuk dapat memahami kehendak orang lain. Oleh sebab itu, kemampuan bahasa merupakan kemampuan yang sangat penting dan harus dimiliki manusia. Kemampuan bahasa harus dilatih sejak usia dini (Kurnia et al., 2015). Banyak orang yang meyakini bahwa perkembangan bahasa itu terjadi sangat pesat pada masa usia dini. (Uce, 2017).

Kegagalan membentuk kemampuan berbahasa anak, bukan hanya menghambat anak dalam kemampuan berkomunikasi saja, akan tetapi menghambatnya pada kemampuan mengakses informasi. (Marisa, 2015). Sebab,bahasa dalam konteks ini dianggap sebagai instrumen dalam memahami suatu ilmu pengetahuan (Agustin, 2015). Selain berdampak pada komunikasi dan akses informasi, kemampuan berbahasa juga berdampak pada aspek sosial anak (Mukhlis \& Mbelo, 2019), dengan keterampilan bahasa yang baik, anak akan lebih mudah untuk berinteraksi dengan orang lain (Khasinah, 2015; Sit, 2017). Bahkan, interaksi sosial anak sebenarnya bermula dari interaksi bahasa dengan orang tuanya bahkan sejak masa dalam kandungan (Suri \& Nelliraharti, 2019; Assingkily \& Hardiyati, 2019). Interaksi bahasa lewat ucapan-ucapan itu tentu mempengaruhi karakter sosial anak (Kambali, 2018), sehingga kelak akan terbentuklah karakter yang mampu beradaptasi dengan sosial sekitar (Khotijah, 2017). Hal ini sesuai dengan fungsi utama bahasa, yakni sebagai alat komunikasi individu dengan individu lainnya, (Yulsyofriend,et.al., 2019).

Secara kuantitatif, kepemilikan kosakata anak pada usia ini sekitar 2000-25.000 perbendaharaan kata (Khadijah \& Armanila, 2017). Melalui bahasa dan kosakata yang dimilikinya, anak dapat mengekspresikan keinginan dan emosionalnya kepada banyak orang (Haryati, 2017; Yuniarti, 2020). Keterampilan bahasa juga dapat di pengaruhi oleh lingkungan sosial anak. Maksudnya, lingkungan di mana anak berinteraksi dan berperilaku sosial akan mempengaruhi keterampilan berbahasa anak (Sumaryanti, 2017). Jika anak cenderung berada pada lingkungan sosial yang selalu menampakkan kekasaran dalam berbicara, maka dengan sendirinya sang anak akan bertutur kata yang kasar juga. Hal ini terjadi karena masa usia tersebut masih dalam taraf imitasi/peniruan (Ulumudin, 2020).

Baik keterampilan bahasa dan sosial, keduanya perlu mendapatkan perhatian khusus dari orang tua dan pendidik (Novrinda et al., 2017). Perhatian yang tidak serius menyebabkan keterlambatan anak dalam berbicara, (Suardi et al., 2019). Secara umum terdapat beberapa faktor yang menyebabkan terjadinya keterlambatan dalam berbicara, di antaranya, 1) faktor kesehatan, 2) Kurangnya perhatian orang tua terhadap perkembangan bahasa anak, 3) Kurangnya suport dari lingkungan sekitar dalam memfasilitasi anak dalam berkomunikasi, 4) kondisi psikis orang tua ketika hamil yang mempengaruhi perkembangan bahasa anak, 6) Strata sosial keluarga (Puspita et al., 2019). Sementara kemampuan berbahasa khususnya pada aspek berbicara itu dikatakan telah dimiliki oleh anak usia dini jika telah memiliki karakteristik, di antaranya 1) Ketepatan dalam ucapan, 2) Penempatan tekanan, nada, sendi, dan durasi yang sesuai, 3) pilihan kata yang tepat, yang sesuai dengan maksud dan tujuan yang hendak di ucapkan, 4) ketepatan sasaran dalam bicara. Ketidakpemilikia empat karakteristik tersebut perlulah menjadi kekhawatiran bagi orang tua terhadap perkembangan bahasa anak (Kurniati et al., 2020).

Abad XXI merupakan masa estapet dari masa sebelumnya yakni era globalisasi (Surya, 2017; Assingkily \& Mesiono, 2019). Ciri khas dari abad ini ditandai pada terjadinya globalisasi hampir pada semua aspek kehidupan manusia (Nata, 2018). Era ini menghendaki tuntutan yang sangat tinggi sekali, era di mana persaingan menjadi sangat terbuka, bukan hanya di dalam negeri tetapi juga antar negara (Sofwan \& Habibi, 2016; Widodo, et.al., 2019). Cirinya ditandai dengan kemampuan dan ketertampilan berpikir kritis dan mengatasi masalah, komunikasi dan kolaborasi, kreativitas dan inovasi. (Rusadi et al., 2019). Agar seseorang dapat menghadapi tantangan di era ini haruslah memiliki pengetahuan, wawasan, skill dan 
kreativitas. Sebab jika tidak mereka akan tergilas dengan waktu dengan sendirinya. (Martini, 2018; Husain, 2020).

Tentu untuk menghadapi era tersebut perlu keterampilan hidup (life skill) yang harus distimulasi sejak dini. Di antara Salah satu keterampilan yang perlu dipersiapkan pada anak usia dini sebagaimana fokus dalam penlitian ini adalah kemampuan bahasa dan sosial. Kemampuan bahasa merupakan modal yang paling utama untuk dapat berkomunikasi bukan hanya antar individu dalam daerah tertapi juga antar individu dengan negara-negara lain. Begitu juga dengan aspek sosial, interaksi dan sikap percaya diri yang tinggi pada setiap individu, tentu menghantarkannya kepada hubungan sosial yang baik pula.

Pembahasan keterampilan bahasa dalam penelitian ini difokuskan pada kemampuan berbicara anak usia 5-6 tahun. Menurut permendikbud No. 146 tahun 2014 bahwa pada masa usia dini anak sudah mampu menunjukkan bahasa ekspresif yakni mengungkapkan perasaan, ide dengan pilihan kata yang sesuai ketika berkomunikasi atau berbicara. Namun kenyataannya terlihat bahwa anak-anak pada usia tersebut rata-rata masih susah untuk dapat mengungkapan perasaan dan ide dari pengalaman-pengalaman yang dimilikinya. Hal semacam di atas, terjadi di TK Rusyda Medan, yang rata-rata pada masa usia tersebut anakanak susah untuk bercerita secara mandiri. Awalnya permasalahan ini muncul disebabkan beberapa hal di antaranya para guru masih saja menggunakan cara-cara yang konvensional, bersikap akademis (bahasa ekspresif yakni mengungkapkan perasaan, ide dengan pilihan kata yang sesuai ketika berkomunikasi atau berbicara) dan anak-anak dijauhkan dari kegiatan bermain. Sangat jarang terlihat anak dilibatkan secara aktif untuk melakukan mengungkapkan perasaan ataupun ide dan gagasannya melalui kegiatan bercerita atau melalui kegiatan bermain. Kegiatan yang tampak dalam keseharian anak akan diberikan beberapa contoh huruf dan kata yang hendak ditulis, lantas meminta anak untuk menulisnya, lalu kemudian nanti bersama-sama dalam membacanya. Hampir setiap hari kegiatan yang terjadi demikian. Kondisi ini dapatlah disimpulkan sebagai pembelajaran yang minim akan inovasi pembelajaran. Kondisi di TK Rusyda tersebut bukan hanya berdampak pada keberhasilan belajar siswa saja, melainkan juga berdampak pada aspek sosialnya.

Anak-anak yang sulit untuk mengolah kata-kata dengan struktur kalimat yang baik tentu akan mengalami masalah berkomunikasi pada lingkungan sosialnya, dalam hal ini kepada teman-temanya tentu ia akan merasa tidak nyaman berada pada lingkungan sosial tersebut, bahkan tak sedikit juga terkadang yang sampai mem-bullying teman-temannya.

Menyikapi hal ini TK Rusyda lantas mencari cara untuk mengatasi hal yang demikian, pada tahun 2019 diterapkanlah strategi 'one week one story (satu minggu, satu cerita) dengan cerita berbasis keislaman seperti pengalaman ibadah, silaturrahim, membaca Al-Qur'an, dan ta'awun. Program ini, diharapkan dapat membantu siswa dalam melatih keterampilan berkomunikasinya. Pilihan konten cerita berbasis keislaman berfungsi secara tidak langsung mendidik mereka untuk rajin beribadah atau mengamalkan nilai-nilai keislaman. Dengan kata lain memaksa mereka untuk selalu hidup dengan nilai-nilai keislaman. Program ini pada awalnya hanya berbentuk kegiatan yang hanya diterapkan kepada beberapa anak saja, dalam arti tidak terprogram. Karena hasilnya dinilai dapat meningkatkan kemampuan bahasa dan sosial anak maka kepala sekolah menjadikannya sebagai program rutin.

Studi pendahuluan yang penulis lakukan menunjukkan bahwa program ini digalakkan pada setiap satu kali dalam seminggu, tujuannya untuk memberikan kesempatan kepada anak-anak di TK Rusyda dalam menceritakan pengalaman yang ia dapat selama melaksanakan 'weekend' bersama dengan keluarganya. Kegiatan tersebut berlangsung hingga saat ini, dan menjadi salah satu strategi andalan di TK Rusyda. Kegiatan tersebut terbilang unik, dan baru, dan dianggap mampu memberikan dampak besar terhadap perkembangan bahasa anak, sehingga menarik perhatian penulis untuk mengetahui dan menganalisis aktivitasnya lebih dalam. Selain mengetahui lebih dalam lagi tentang program ini, tentu akan dapat mengeluarkan rekomendasi dan saran kepada TK-TK yang lain untuk dapat menerapkan hal yang sama. 
Sejatinya, kajian mengenai program pengembangan bahasa dan sosial AUD di abad 21 sudah diteliti oleh sejumlah orang. Di antaranya membahas meningkatkan komunikasi AUD melalui metode cerita gambar (Syukur \& Tefanai, 2017), pengembangan bahasa AUD melalui buku cerita (Aris \& Kusumaningrum, 2017), pengaruh mendengarkan cerita dan membaca cerita terhadap kemampuan bahasa lisan (Isbell et al., 2004), membangun komunitas di kelas AUD melalui cerita berdongeng (Wright et al., 2013), pengembangan pembelajaran Bermain, cerita, menyanyi dalam konteks pengembangan sosial (Aprianti, 2018), penerapan cerita daerah untuk meningkatkan kemampuan interaksi sosial anak (Septi \& Eliza, 2019), peningkatan kemampuan sosialisasi anak melalui metode cerita (Hasanah, 2011).

Berdasarkan literature review di atas, diketahui bahwa terdapat "ruang kosong" pengembangan kemampuan bahasa melalui program one week one story. Dengan demikian diperlukan analisis yang lebih terkait dengan hal ini, yang di bingkai dengan judul penelitian "Program One Week One Story Berbasis Keislaman Pada Aud Untuk Bekal Keterampilan Abad 21 ". Secara khusus tujuan penelitian ini untuk menganalisis problematika bahasa dan sosial yang dialami oleh AUD di TK Rusyda Medan, latar belakang munculnya strategi one week one story, penerapan strategi one week one story, kendala yang dihadapi dalam peneerapan one week one story.

Jika dibandingkan dengan penelitian sebelumnya, keunggulan penelitian ini terletak pada kajian program pembelajaran yang memang relevan diterapkan dan sesauai dengan tuntutan di era abad 21. Oleh karena itu tentunya penelitian ini sangat bermanfaat bagi guru dalam hal memenuhi tuntutan kecerdasan anak di era abad 21. Selain itu dapat menjadi rekomendasi program khusus bagi lembaga pendidikan bidang anak usia dini dalam menyahuti dan menghadapi pendidikan di era adab 21.

\section{METODOLOGI}

Penelitian ini dilaksanakan di TK Rusyda Medan yang beralamat di Jl. Bromo Gg. Satia No 5, kelurahan Binjai, Kec. Medan Denai, Kota Medan Prov. Sumatera Utara. Dilaksanakan selama 4 bulan, terhtung dari November 2019 sampai dengan Februari 2020. Alasan untuk memilih lokasi penelitian ini dikarenakan TK tersebut menerapkan strategi tersebut dan dari beberapa TK yang berada di sekitaran TK tersebut hanyalah TK Rusyda yang menerapkan program tersebut. Di samping itu, pemilihan lokasi ini juga dikarenakan permasalahan yang terjadi di TK tersebut yakni rata-rata masih susah untuk mengungkapan perasaan dan ide dari pengalaman-pengalaman yang dimiliki. Terkait dengan proses pengumpulan data di lapangan, dalam hal ini penulis mengambil waktu setiap hari senin saja, hal ini dikarenakan program one week one story hanya dilaksanakan di hari senin, yang setelah satu hari sebelumnya siswa libur weekend. Alur penelitian seperti yang tertera pada bagan 1.

Adapun yang menjadi partisipan penelitiannya ialah guru-guru TK Rusyda Medan yang mengajar di kelas B yang terdiri dari 2 kelas yakni sebanyak 5 orang dan siswa di kelas $\mathrm{B}$ tersebut yang berjumlah 30 orang. Kelas A dalam penelitian ini tidaklah di ikutsertakan sebab secara kurikulum keterampilan mengungkapkan perasaan, gagassan, dan ide hanyalah di targetkan pada anak usia 5-6 tahun atau dalam hal ini kelas B. Sebagaimana fokus penelitian ini maka penelitian ini difokuskan pada partisipan di kelas B saja.

Pendekatan penelitian yang digunakan ialah penelitian kualitatif, dengan metode deskriptif. Dalam hal ini dekskripsi akan lebih banyak untuk memberikan ulasan berupa gambaran nyata dan komprehensif terkait dengan pelaksanaan pembelajaran berkomunikasi dengan menggunakan program one week one story. Penelitian ini menggunakan teknik observasi, wawancara dan dokumentasi. Dalam proses pengumpulan datanya. Observasi dilakukan untuk mengamati secara lansung tentang praktik pelaksanaan one week one story di TK Rusyda Medan. Sedangkan wawancara sebanyak 15 butir pertanyaan seputar problematika keterampilan bahasa dan sosial (3 butir), latar belakang penerapan program one week one story ( 3 butir), pola penerapan program ( 3 butir) respon siswa tentang penerapan program tersebut (3 butir), kendala yang dihadapi dalam penerapan (3 butir). Sedangkan studi 
dokumentasi untuk melihat tentang rencana pelaksanaan harian guru tersebut, dan daftar penilaian hasil belajar siswa. Dalam hal ini untuk mengetahui tentang desain atau rencana dalam penerapan program tersebut, dan analisis ketercapaian. Analisis data menggunakan model Miles dan Huberman, dimana mereka menawarkan 4 langkah dalam menganalisis data penelitian yakni reduksi data, penyajian data, dan penarikan kesimpulan.

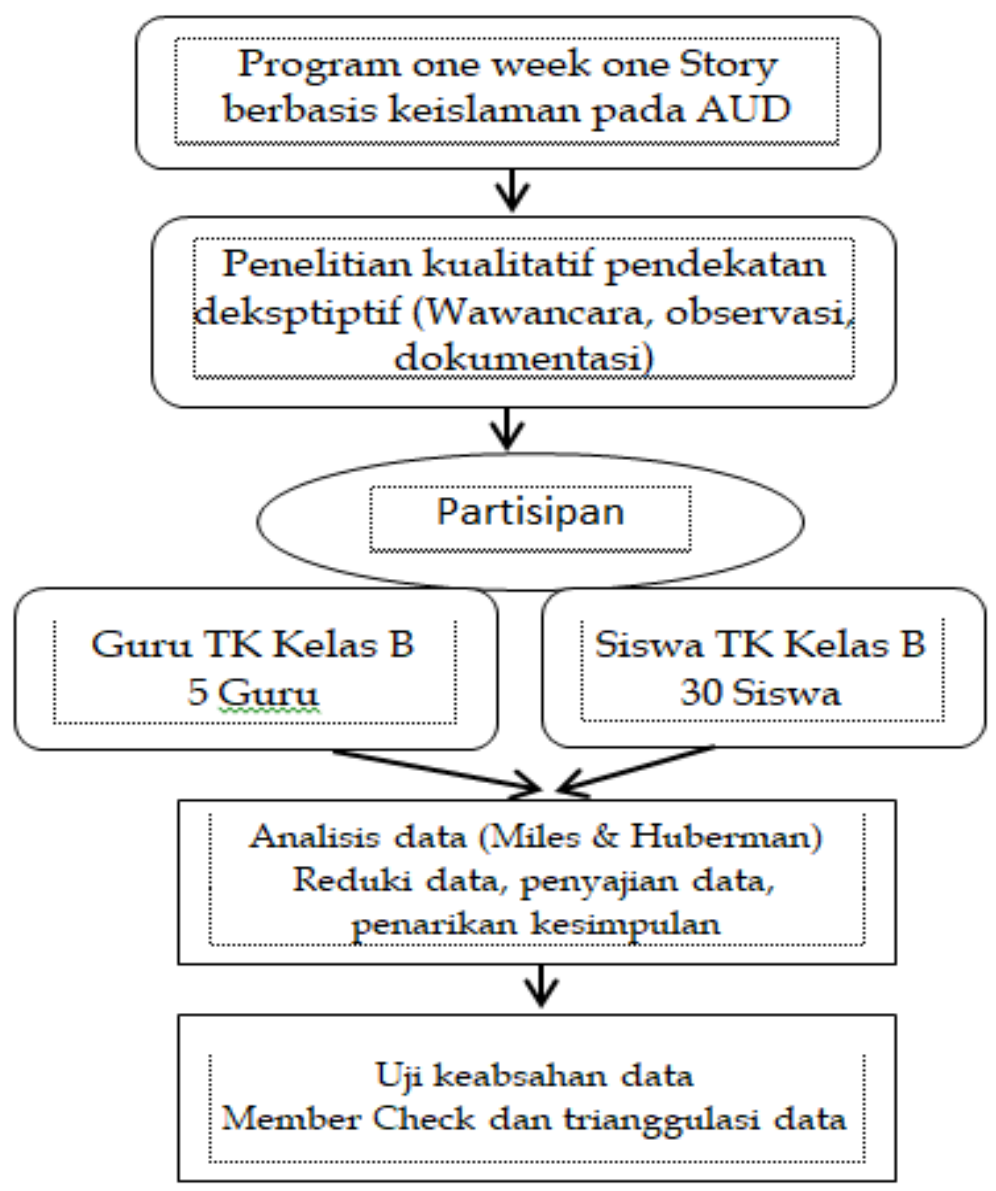

Bagan 1. Alur penelitian

\section{HASIL DAN PEMBAHASAN}

Sistematika penjelasan temuan dan pembahasan hasil penelitian akan diruntut berdasarkan masalah dan tujuan penelitian, yakni problematika bahasa dan sosial, latar belakang munculnya strategi one week one story, penerapan strategi one week one story, kendala yang dihadapi dalam peneerapan one week one story. Secara jelas diuraikan berikut:

\section{Problematika Kemampuan Bahasa dan Sosial AUD TK Rusyda Medan}

Hasil pengamatan tentang kemampuan bahasa AUD di TK Rusyda Medan, memang menunjukkan terdapat beberapa permasalahan. Untuk mengamatinya penulis mendasarkannya pada indikator sebagaimana yang tertera dalam Permendikbud No. 146 tahun 2014. Namun yang akan dicantumkan sebagaimana fokus pembahasan hanya pada aspek berbicara saja. Secara rinci dapat dilihat pada tabel 1.

Dari penjelasan pengamatan tabel 1 tampak bahwa terdapat beberapa anak yang belum mencapai indikator pencapaian sebagaimana yang telah ditetapkan dalam Permendikbud tersebut. Hasil pengamatan ini semakin menguatkan penelitian sebelumnya yang menunjukkan bahwa problematika kemampuan berbicara anak berbentuk kesulitan dalam pengolahan kata untuk bercerita, sehingga berdampak pada kemampuan interaksi sosialnya. 
Tabel 1. Hasil Pengamatan Problematika Kemampuan Bahasa Anak

\begin{tabular}{|c|c|c|c|}
\hline No & Indikator Pencapaian & Hasil Pengamatan & Keterangan \\
\hline 1 & $\begin{array}{l}\text { Menceritakan kembali } \\
\text { apa yang didengar } \\
\text { dengan kosakata yang } \\
\text { lebih }\end{array}$ & $\begin{array}{l}25 \text { anak dapat menceritakan } \\
\text { dengan kosakata lebih dan } 5 \\
\text { anak tidak dapat menceritakan }\end{array}$ & $\begin{array}{l}\text { Menceritakan } \\
\text { pengalaman saat } \\
\text { berlibur }\end{array}$ \\
\hline 2 & $\begin{array}{l}\text { Mengungkapkan } \\
\text { keingingan, perasaan, } \\
\text { dan pendapat dengan } \\
\text { kalimat sederhana dalam } \\
\text { berkomunikasi dengan } \\
\text { anak atau orang dewasa }\end{array}$ & $\begin{array}{l}\text { Seluruh anak mampu untuk } \\
\text { mengungkapkan perasaaan } \\
\text { dalam kalimat sederhana. } \\
\text { Namun terdapat beberapa } \\
\text { gangguan seperti fonetik } \\
\text { (pelafalan kosakata yang tidak } \\
\text { tepat, missal 'mam' untuk } \\
\text { maksud 'makan), sintaksis } \\
\text { (susunan kalimat yang tidak } \\
\text { tepat, misal 'pergi jangan lama- } \\
\text { lama pulang', yang dimaksud } \\
\text { 'silahkan pergi, tetapi cepat } \\
\text { kembali' }\end{array}$ & $\begin{array}{l}\text { Mengungkapkan } \\
\text { keinginan seperti } \\
\text { permisi izin ke } \\
\text { kantin, dan toilet. }\end{array}$ \\
\hline 3 & $\begin{array}{l}\text { Mengungkapkan } \\
\text { perasaan, ide dengan } \\
\text { pilihan kata yang sesuai } \\
\text { ketika berkomunikasi }\end{array}$ & $\begin{array}{l}20 \text { orang anak dengan lancar } \\
\text { dan berani menyampaikan } \\
\text { pengalamannya, dan } 10 \text { orang } \\
\text { anak mampu tetapi kurang } \\
\text { lancar }\end{array}$ & $\begin{array}{l}\text { Menceritakan } \\
\text { pengalaman } \\
\text { berlibur }\end{array}$ \\
\hline 4 & $\begin{array}{l}\text { Menceritakan kembali } \\
\text { isi cerita secara } \\
\text { sederhana }\end{array}$ & $\begin{array}{l}20 \text { orang anak dengan lancar } \\
\text { menceritakan pengalaman } \\
\text { berliburnya yang terkait dengan } \\
\text { keislaman seperti pengalaman } \\
\text { beribahdan dengan orang tua } \\
\text { bersilaturrahim, membaca Al- } \\
\text { Quran saat libur. Dan } 10 \text { orang } \\
\text { tidak mampu menyampaikan } \\
\text { cerita }\end{array}$ & $\begin{array}{l}\text { Menceritakan } \\
\text { pengalaman saat } \\
\text { libur yang berkaitan } \\
\text { dengan aktivitas } \\
\text { keislaman }\end{array}$ \\
\hline
\end{tabular}

Berdasarkan wawancara dengan salah seorang pengajar di TK Rusyda Medan, yakni ibu Ria, bahwa problematika siswa tersebut disebabkan karena beberapa hal, sebagaimana beliau menuturkan:

"Kesulitan anak-anak di TK ini dalam berbicara dan bercerita lebih dikarenakan kurangnyaa perhatian dari orang tua. Bahkan siswa di TK kita ini ada beberapa anak yang tinggalnya tidak bersama dengan orang tua mereka akan tetapi bersama nenek dan kakeknya, sementara orang tuanya telah bercerai. Tentu beda lah kalau ibu dan nenek yang mengasuh, kalau nenek dan kakek kan sudah tua, tenaga dan pikirannya kan berkurang tentu tidaklah dapat maksimal dalam mengajarkan cucunya"

Terkait dengan problematika pembelajaran bahasa yang dialami oleh anak di TK Rusyda Medan menyangkut konten-konten kegiatan bercerita yang minim dengan konten cerita berbasis aktivitas keislaman anak selama di rumah, hal ini sebagaimana dituturkan oleh ibu Regi:

"Pembelajaran bahasa dengan menggunakan metode bercerita, hampir rata-rata kontennya itu seputar kegiatan berlibur mereka, sangat jarang terdengar anak-anak yang bercerita tentang kegiatan liburnya yang diisi dengan kegiatan keislaman, padahal salah satu misi lembaga ini hendak membiasakan anakanak untuk menjadi insan yang islami, baik dalam perkataan, maupun juga perbuatan" 
Sedangkan problematika kemampuan sosial jika dihubungkan dengan kemampuan bahasa, di antaranya 1) anak cenderung merasa sulit tatkala berkomunikasi dengan teman dan gurunya, 2) anak cenderung ditertawakan oleh teman-temannya karena aspek sintaksis (runtutan susunan kalimat) rendah, 3) anak cenderung ditertawaan oleh teman-temannya karena pelafalan kata yang seyogiaya tidaklah tepat jika diucapkan lagi pada masa usianya, 4) anak kerap merasa kurang percaya diri untuk berbicara di hadapan orang banyak, sebab tak mampu untuk mengungkapkan pengalaman yang telah dialaminya. 5) anak kerap juga ditertawakan karena kerap menggunakan bahasa daerah saat berbicara, hal ini terkontaminasi dari ucapan orang tua yang selalu digunakan dalam kehidupan sehari-hari.

Temuan tentang problematika ini berbeda dengan penelitian sebelumnya dan relevan, seperti temuan dalam penelitan Syukur \& Tefanai (2017), Aris \& Kusumaningrum (2017), dan Aprianti (2018), yang kesemuanya menunjukkan bahwa problematika kemampuan berbicara dikarenakan intensitas atau kurangnya pembiasaan. Sementara penelitian ini menunjukkan bahwa problematika keterampilan berbicara juga dikarenakan faktor ketidaktepatan dalam penentuan konten cerita dan penggunaan strategi.

\section{Latar belakang munculnya program One Week One Story di TK Rusyda Medan}

Program ini bermula dari kekhawatiran pendidik terhadap keterampilan berbicara anak di TK Rusyda Medan. Hasil wawancara dengan 5 guru di kelas B dijelaskan bahwa awal mulanya sangat banyak anak yang tidak mampu untuk bercerita sesuai dengan perasaan dan ide yang mereka alami sebelumnya. Bahkan jarang sekali terlihat adanya siswa yang mampu untuk menceritakan pengalamannya di depan kelas. Padahal beberapa kali mulanya guru bertanya kepada beberapa siswa tentang pengalamannya selama libur weekend namun hal tersebut hanya di sambut dengan jawaban-jawaban singkat saja.

Guru mengemukakan bahwa problem ini sebenarnya tampak bahwa dalam hal ini anak bukanlah tak mampu untuk merespon pertanyaan sang guru. Namun yang menjadi problem yakni ketidakmampuan siswa untuk menguraikan secara panjang lebar tentang halhal yang ia alami selama libur weekend. Disamping itu apa yang dikemukakan guru itu menunjukkan bahwa pada mulanya TK tersebut tidaklah terbiasa untuk mengemukakan pendapat atau ide, gagasan sederhana di depan kelas. Bahkan menurut penuturan dari guru, bahwa hal ini pada mulanya menjadi salah satu momok yang menakutkan dan memalukan bagi anak-anak tersebut.

Di samping itu, latar belakang munculnya karena guru-guru mengangap bahwa kemungkinan terjadinya problematika keterampilan berbicara itu dikarenakan penggunaan metode pembelajaran yang cenderung kepada konvensional dan akademis. Atau dengan kata lain pembelajaran dilaksanakan secara kaku dan terlalu bersifat formal. Sehingga pembelajaran menjadi terlihat kaku, dan kurang menarik. Hal ini tampak dari aktivitas rutin yang mungkin dapat hampir dikatakan sulit untuk ditinggalkan yakni menulis dan membaca dari apa yang telah dicontohkan oleh guru.

Kegiatan ini digambarkan seperti kegiatan menulis yang telah di contohkan guru di papan tulis, lalu meminta kepada siwa untuk menulisnya secara berulang dalam beberapa baris, lantas kemudian meminta siswa untuk membaca bersama dengan teman-teman yang lain secara berulang-ulang. Dalam kegiatan ini tampak bahwa tidaklah target pencapaian agar anak tersebut dapat terampil dalam berbicara atau berkomunikasi. Justru menurut hemat penulis malah membuat anak kaku dan sulit untuk mengungkapkan perasaannya.

Menyikapi hal ini lantas guru-guru TK Rusyda berisiatif untuk mencari solusi dari permasalahan ini. Maka menurut penuturan dari para guru di TK Rusyda bahwa ketika itu sepakat untuk memberikan ruang dan waktu kepada siswa agar mereka lebih memiliki waktu dan kondisi yang bebas untuk menyampaikan gagasan atau ide-idenya tersebut. Maka pada waktu itu timbullah kesepakatan bahwa dalam satu minggu harus diberikan ruang kepada anak untuk menyampaikan pengalaman-pengalaman mereka selama weekend. Pemilihan Weekend ini dilakukan karena ketika itu para guru berasumsi bahwa waktu libur ialah waktu 
yang paling digemari oleh anak-anak. Pada hari tersebut akan sanga banyak hal yang dapat dilakukan oleh siswa, mulai pergi rekreasi bersama dengan keluarga, pergi bermain bersama dengan teman, atau pun jika tidak berpergian kemana-mana paling tidak anak-anak tersebut telah melakukan kegiatan lain yang di luar dari kegiatan rutinitasnya yakni sekolah dan belajar.

Maka tepatnya setahun yang lalu yakni pada tahun 2019 kepala sekolah TK Rusyda Medan mengeluarkan gagasan yang ketika itu ia sebut dengan 'pekan bercerita'. Namun beberapa waktu kemudian istilah tersebut di ubah menjadi 'one week one story'. Alasan perubahan istilah ini bukanlah menyentuh sesuatu hal yang substantif, melainkan hanya keinginan agar kata tersebut lebih modern saja dan kemudahan dalam mengingatnya semata (Alfiansya, et.al., 2020).

Alasan terkahir yang melatarbelakangi munculnya ide program ini ialah sebagai wujud membiasakan mereka untuk terampil berbicara di depan umum. Menurut para guru salah satu faktor yang hilang dari ciri khas anak bangsa Indonesia ialah kurangya kemampuan untuk berbagi cerita dan berkomunikasi di depan umum. Hal ini menurut mereka tampak dari sedikitnya anak-anak yang mampu untuk berkata yang bijak di depan umum, dan berkata yang sopan di depan umum. Maka berdasarkan asumsi itulah para guru di TK Rusyda menggalakkan program tersebut.

Berbeda dengan penelitian sebelum-sebelumnya seperti temuan Syukur \& Tefanai (2017), Aris \& Kusumaningrum (2017), dan Aprianti (2018), yang kesemuanya pemilihan strategi lebih berorintasi pada solusi problematia keterampilan berbicara yang sedang dialami saat itu, sementara penelitian ini menunjukkan bahwa latar belakang pemilihan dan penetapan strategi keterampilan berbicara one week one story juga berorientasi pada masa depan anak, dimana anak dipersiapkan untuk mampu menghadapi era revolusi industri 4.0 yang penuh dengan ragam tantangan.

\section{Pelaksanaan Kegiatan One Week One Story berbasis keislaman di TK Rusyda}

Seperti yang telah dikemukakan di atas bahwa kegiatan tersebut dilaksanakan pada setiap hari senin. Pemilihan hari ini dikarenakan karena pada hari minggunya siswa melaksanakan libur weekend sehingga sangatlah cocok untuk meminta anak-anak dalam menceritakan pengalaman mereka dari yang mereka alami pada hari libur tersebut. Di samping itu pemilihan hari ini bertujuan untuk menjaga ingatan siswa, sebab ketika di hari senin tentu ingatan mereka masih segar, sehingga mereka mudah untuk menceritakannya kembali bersama dengan teman-temanya. Tetapi jika dilaksanakan setelah beberapa hari tentu nya nanti membuat siswa susah untuk mengingatnya.

Program ini dilaksanakan secara lisan oleh siswa dan dibimbing oleh guru-guru langsung. Berdasarkan pengamatan penulis, tampak biasanya sang guru meminta siswa untuk duduk bersama di lantai dengan cara membentuk lingkaran dan meminta setiap siswa secara bergiliran untuk bercerita. Kegiatan di atas, dapat dilihat pada gambar 1.

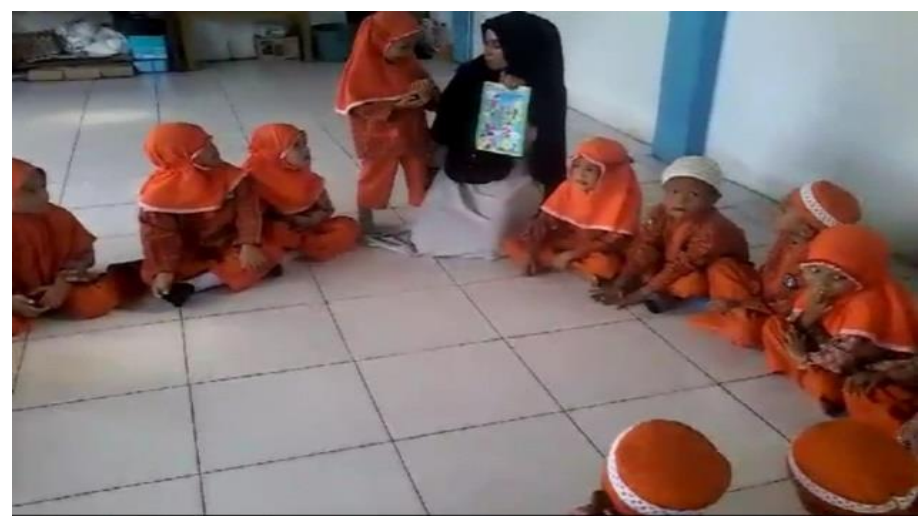

Gambar 1. Kegiatan one week one story di TK Rusyda 
Adapun dalam hal konten cerita, sebenarnya di batasi untuk bercerita terkait dengan pengalaman atau aktivitas keislaman yang dialami pada hari sebelumnya. Kegiatan keislaman yang dimaksud seperti kegiatan beribadah ke masjid bersama dengan orang tua, kegiatan shalat berjamaah dirumah dengan orang tua, kegiatan mengaji bersama dengan orang tua, kegiatan menghafal surah dan hadis bersama orang tua, kegiatan bersiaturahim kerumah sanak saudara, kegiatan bersedekah dan lainnya. Akan tetapi mengingat tidak semua siswa melakukan hal itu, maka guru juga memperkenankan anak untuk menceritakan pengalaman lain seperti berolah raga dengan orang tuanya, rekreasi, membersihkan lingkungan, dan kegiatan anak-anak yang bermain dengan teman sebayanya. Penjelasan hal ini sebagaimana dituturkan oleh ibu Fitri:

"anak-anak kita minta untuk bercerita tentang kegiatan keislamannya seperti ibadah dengan orang tua, mengaji dan berdoa bersama, bersilaturrahim, kegiatan bersedekah, dan sebagainya. Tujuannya agar anak-anak kita terbiasa mengisi waktu libur dengan kegiatan yang bermanfaat, dan terbiasa hidup dengan nuansa keislaman. Namun, tidaklah semua anak melakukan kegiatan itu, ya....kita perbolehkan juga lah mereka untuk cerita yang lain, yang penting dia tetap berani bercerita"

Adapun perihal yang perlu menjadi titik tekan di sini ialah TK Rusyda tidak memberikan batasan cerita pada satu judul tertentu melainkan diprioritaskan pada cerita berbasis nilai keislaman. Dalam hal ini, guru meminta siswa secara bebas untuk mengemukakan pendapat, ide dan gagasannya melalui cerita pengalaman hari liburnya dengan etika dan sopan santun yang dibimbing oleh guru. Dari hal ini, penulis mengambil sebuah kesimpulan bahwa hal ini dilakukan karena penilaian terhadap sisi substantifnya, yakni kegiatan melatih siswa untuk bercerita. Bukan kegiatan untuk mengalisis isi ceritanya. Pada praktiknya guru akan ikut bersama dengan teman-teman lain utnuk mendengarkan bersama cerita-cerita dari teman-temanya. Pengamatan penulis terhadap kegiatan ini tampak bahwa setiap siswa mampu untuk bercerita kurang lebih sekitar 5-7 menit saja. Bahkan itu pun sebenarnya sudah disertati dengan senda gurau dan canda tawa terhadap hal-hal humoris yang disampaikan oleh teman-temannya.

Fungsi guru dalam kegiatan ini, tampak seperti sosok yang memeberikan support dan membantu siswa untuk memperbaharui kosa kata siswa. Sebab dalam hal ini banyak sekali ditemukan beberapa siswa yang sulit untuk mengungkapkan pengalamannya disebabkan karena kurangnya perbendaharaan kata yang dimilikinya. Pada kondisi dan situasi inilah guru berperan sebagai pendidik yang membantu para peserta didik untuk memperkenalkan kata-kata baru di hadapan peserta didiknya. Dengan memperkenalkan kosa kata baru tentu bermanfaat terhadap perbendaharaan kata siswa. Hal ini dilakukan sebab secara psikologi pada masa inilah siswa belajar dengan perkembangan yang sangat pesat, anak-anak akan mampu untuk meyimpan banyak informasi terkait dengan hal-hal baru yang ia dapat, termasuk lah dalam hal ini kata-kata yang baru. Beberapa kata baru itu di antaranya ialah kata-kata yang tak biasa didengar oleh siswa seperti kata masyarakat (lazimnya mereka menyebut 'orang-orang'), rekreasi (lazimnya mereka menyebut 'jalan-jalan'), dan lain sebagainya.

Kegiatan ini terlaksana dengan bentuk pembelajaran tentang ekspresi sikap dari sesuatu yang dialami, seperti pengungkapan rasa gembira, pengungkapan rasa sedih, pengungkapan rasa bangga, peengunggkapan rasa jengkel dan kecewa. Hal ini bertujuan untuk membina sikap siswa sejak dini, sekaligus mengkoordinasikan kemampuan Bahasa mereka dengan sikap dan bahkan dengan kemampuan motorik. Dikaitkan dengan motorik sebab bisa saja dalam pengungkapan perasaan tersebut siswa menggunakan tangan dan raut wajah sebagai gestur atau ekspresi dalam bercerita.

Selain itu dalam kegiatan ini kegiatan guru selain sebagai pembimbing dan pemberi motivasi, guru juga memberikan penilaian terhadap seluruh cerita yang dikemukakan oleh siswa. Namun dalam hal ini penilaian tidaklah diartikan sebagai penilaian dalam bentuk soal 
atau ujian sebagaimana lazimnya ujian. Penilaian ini hanya sebatas untuk melihat progres anak dalam kemampuannya berkomunikasi di depan umum. Beberapa penggunaan kata yang salah, dan penggunaan sikap dan ekspresi yang salah dalam hal ini langsung saja diperbaiki oleh guru. Hal ini dimaksudkan agar siswa dapat lebih peka terhadap kesalahankesalahan yang mereka lakukan dan segera memperbaikinya.

Guru juga melakukan kerja sama kepada orang tua, dalam hal memberikan saran kepada orang tua agar merekam semua aktivitas anak tersebut selama liburan, dan mengajari anak-anak mereka untuk menyampaikan ceritanya di hadapan orang banyak. Jadi dalam hal ini kegiatan dilaksanakan seimbang antara aktivitas guru dengan aktivitas orang tua di rumah.

Dalam kaitannya dengan aspek sosial kegiatan ini melatih siswa untuk dapat menyampaikan ide (pengalamannya) dengan sopan dan santun di hadapan banyak orang. Selain itu strategi ini juga menghendaki siswa untuk menyimak dengan seksama terhadap pengalaman yang disampaikan oleh temannya, Tanpa disadari mereka belajar tentang menghargai dan menghormati orang lain. Dari hal ini juga guru dapat mengurangi perilaku bullying yang kadang kala dilakukan oleh anak-anak.

Keterampilan abad 21 di antaranya seseorang memiliki kemampuan komunikasi dan kolaborasi (communication and collaboration). Tentu strategi one week one story ini diharapkan dapat memicu anak agar kelak terbiasa terampil dalam berkomunikasi bahkan terampil dalam mengemas ide dan pengalaman dalam bentuk ujaran yang baik. Menurut hemat penulis tentu pengetahuan tidak akan berbuah manakala tidak tersampaikan kepada orang lain. Dan cara menyampaikan pengalaman tersebut tentu dengan cara berkomunikasi baik lewat lisan maupun tulisan.

One Week One Story dijadikan sebagai wujud implementasi mempersiapkan generasi abad 21. Sebab karakteristik pembelajaran abad 21 menjadikan guru menjadi lebih sedikit aktivitas berceramahnya, guru abad 21 lebh cenderung dalam memfasilitasi anaknya agar belajar mandiri. Strategi One Week One Story memiliki karekteristik ini, siswa secara mandiri mengemukakan gagasannya, sehingga bebas menuangkan segala ekspresinya. Walaupun secara praktik mungkin terdapat beberapa kesalahan, ataupun perulangan cerita-cerita dari hari-hari sebelumnya, namun yang titik tekannya bukan kepada konten melainkan kepada pengalaman belajar mandiri tersebut.

Program one week one story memiliki perbedaan dengan program lainnya yang telah diteliti oleh peneliti-peneliti sebelumnya, terutama dalam hal sarana yang dimanfaatkan. Seperti penelitian Aprianti (2018), yang memanfaatkan kegiatan bernyanyi dan bermain, penelitian Septi \& Eliza (2019), yang memanfaatkan cerita daerah untuk keterampilan berbicara, penelitian Syukur \& Tefanai (2017), yang memanfaatkan cerita bergambar. Program one week one story memanfaatkan pengalaman siswa itu sendiri, terutama yang keislaman. Program ini tidak hanya menghendaki untuk bercerita saja akan tetapi membiasakan mereka dalam nuansa hidup yang islami.

\section{Kendala yang dihadapi dalam pelaksanaan dalam penerapan one week one story}

Pengamatan penulis terkait dengan kendala yang dihadapi oleh guru dan siswa terkait dengan pelaksanaan program ini, tidaklah terdapat kendala yang berarti. Di bawah ini akan diuraikan beberapa kendala yang dihadapi oleh guru:

Pertama, jumlah guru yang tidak sebanding dengan jumlah siswa. Jumlah guru yang mengajar dikelas tersebut hanyalah dua orang untuk tiap satu kelas, sementara jumlah siswa mencapat 27 orang. Hal ini tentu membuat kelas menjadi riuuh dan bising tatkala program tersebut berlangsung

Kedua, kurangnya kerja sama orang tua dan guru. Sebagaimana yang telah dikemukakan di atas bahwa program ini akan terselenggara dengan baik mana kala terdapat kerjasama antara orang tua dan guru, namun hal itu tidaklah dilaksanakan oleh semua orang tua. Ada saja beberapa orang tua yang bersikap acuh atau tidak mau tau tentang 
perkembangan Bahasa anak-anaknya. Rerata anak yang tak mampu bercerita, lebih disebabkan karena ketidakpedulian orang tua terhadap aktivitas anak-anaknya.

Ketiga, hasil pengamatan penulis bahwa kegiatan program ini akan sangat ekeftif dan menarik di awal-awal saja, sedangkan setelah berjalan beberapa siswa terlihat bosan untuk mendengarkan cerita teman-temannya. Hal ini disebabkan karena jumlah atau forsi siswa yang tak sebanding dengan jumlah guru sebagaimana yang telah dikemukakan sebelumnya. Seharusnya jika jumlah nya seimbang maka waktu untuk pelaksanaan program tersebut tidaklah terlalu lama, dan tentu tidak akan menimbulkan kejenuhan kepada siswa.

Keempat, siswa susah untuk penyampaian cerita karena sulit dalam menyusun kalimat yang terstruktur. Memang kendala terbesar yang dihadapi ialah rancu atau tidak runtutnya kalimat siswa dalam penuturan cerita-cerita mereka. Sehingga jika tidak didampingi oleh pembimbing, beberapa orang mungkin tidak akan mengerti dengan cerita mereka. Pada posisi inilah fungsi pembimbing untuk mengarahkan siswa menyusun kalimat sehingga kalimat yang disamoaikan sesuai dengan kehendak atau maksud dari yang ingin di sampaikan.

Kelima, siswa susah untuk meyusun runtutan cerita. Hal ini juga menjadi kendala bagi siswa, walaupun pada dasarnya hal itu adalah yang wajar terjadi pada anak usia dini. Hanya saja disebut kendala karena ketidak tuntutan certia tersebut membuat orang susah untuk memahami cerita anak-anak tersebut.

\section{SIMPULAN}

Program one week one story diterapkan untuk mengatasi problematika kemampuan bahasa dan sosial anak usia dini yang terjadi TK Rusyda. Program ini dilaksanakan satu minggu sekali dalam bentuk kegiatan siswa menceritakan pengalaman liburya di akhir pekan. Konten cerita yang diharuskan pada batasan kegiatan keislaman siswa selama libur di akhir pekan. Dalam penerapannya terdapat beberapa kendala yang dihadapi yakni rasio guru dan siswa yang tidak sebanding dan kurangnya kerjasama guru dan orang tua. Hasil penelitian ini direkomendasikan kepada guru dan pengelola lembaga pendidikan TK dalam hal pengembangan kemampuan bahasa dan sosial.

\section{UCAPAN TERIMA KASIH}

Peneliti mengucapkan terimakasih banyak kepada Kepala TK Rusyda Medan yang telah memberikan izin dan fasilitas riset, dan kepada para partisipan yakni guru, siswa, dan orang tua yang telah bersedia memberi informasi terkait program one week one story yang telah dilaksanakan di TK Rusyda Medan.

\section{DAFTAR PUSTAKA}

Agustin, Y. (2015). Kedudukan bahasa Inggris sebagai bahasa pengantar dalam dunia pendidikan. Deiksis, 3(04), 354-364. http:/ / dx.doi.org/10.30998/deiksis.v3i04.440

Amri, N. A. (2017). Pengaruh Metode Bermain Peran Terhadap Kemampuan Komunikasi (Bahasa Ekspresif) Anak Taman Kanak-Kanak Raudhatul Athfal Alauddin Makassar. Pembelajar: Jurnal Ilmu Pendidikan, Keguruan, Dan Pembelajaran, 1(2), 105-110. https:// doi.org/10.26858/pembelajar.v1i2.4864

Aprianti, E. (2018). Penerapan Pembelajaran Bcm (Bermain, Cerita, Menyanyi) Dalam Konteks Perkembangan Sosial Emosional Anak Usia Dini Di Kober Baiturrohim Kabupaten Bandung Barat. Tunas Siliwangi: Jurnal Program Studi Pendidikan Guru Paud STKIP Siliwangi Bandung, 3(2), 195-211. https:// doi.org/10.22460/ts.v3i2p195-211.651

Aris, A., \& Kusumaningrum, A. T. (2017). Pengembangan Kemampuan Berbahasa Melalui Metode Cerita Dengan Membacakan Buku Cerita Bermedia Gambar Pada Anak Pra Sekolah. Jurnal Keperawatan Muhammadiyah, 2(2), 150-158. http:/ / dx.doi.org/10.30651/jkm.v2i2.1096 
Creswell, J. w. (2018). Penelitian Kualitatif dan Desain Riset; Memilih di Antara Lima Pendekatan (5th ed.). Pustaka Pelajar.

Haryati, D. (2017). Stimulasi Pengembangan Kecerdasan Verbal-Linguistik Anak Usia Dini Melalui Metode Pembelajaran Paud. Elementary: Jurnal Ilmiah Pendidikan Dasar, 3(2), 132-143. https:/ / doi.org/10.32332/elementary.v3i2.995

Hasanah, A. (2011). Pelaksanaan metode cerita untuk meningkatkan kemampuan sosialisasi anak usia dini di TK Tarbiyatul Athfal 14 Plantaran Kaliwungu Kendal [IAIN Walisongo]. http://eprints.walisongo.ac.id/2129/

Isbell, R., Sobol, J., Lindauer, L., \& Lowrance, A. (2004). The Effects of Storytelling And Story Reading on the Oral Language Complexity and Story Comprehension Of Young Children. Early Childhood Education Journal, 32(3), 157-163. https://doi.org/10.1023/B:ECEJ.0000048967.94189.a3

Kambali. (2018). Pertumbuhan Dan Perkembangan Emosional Serta Intelektual Di Masa Prenatal. Risâlah, Jurnal Pendidikan Dan Studi Islam, 4(2, Sept), 129-148. https://doi.org/10.31943/jurnal_risalah.v4i2.87

Khadijah, \& Armanila. (2017). Bermain dan Permainan Anak Usia dini. Perdana Publishing.

Khasinah, S. (2015). Interaksi Ekstratekstual dalam Proses Bercerita Kepada Anak Usia Dini. Gender Equality: International Journal of Child and Gender Studies, 1(1), 99-110. http://dx.doi.org/10.22373/equality.v1i1.782

Khotijah, K. (2017). Strategi Pengembangan Bahasa Pada Anak Usia Dini. Elementary: Jurnal Ilmiah Pendidikan Dasar, 2(2), 35-44. https://ejournal.metrouniv.ac.id/index.php/elementary/article/view/strategipengembahan-bahasa-anak-usia-dini

Kurnia, D., Taufiq, M., \& Silawati, E. (2015). Analisis Capaian Perkembangan Bahasa Anak Usia Dini dalam Kegiatan Pembelajaran dengan Metode Learning Based Resources. Cakrawala Dini: Jurnal Pendidikan Anak Usia Dini, 6(2), 61-70. https://doi.org/10.17509/cd.v6i2.10520

Kurniati, E., Alfaeni, D. K. N., \& Andriani, F. (2020). Analisis Peran Orang Tua dalam Mendampingi Anak di Masa Pandemi Covid-19. Jurnal Obsesi: Jurnal Pendidikan Anak Usia Dini, 5(1), 241-256. https:// doi.org/10.31004/obsesi.v5i1.541

Marisa, R. (2015). Permasalahan Perkembangan Bahasa dan Komunikasi Anak. JPsd (Jurnal Pendidikan Sekolah Dasar), 1(2), 47-55. http:/ / dx.doi.org/10.30870/jpsd.v1i2.694

Martini, E. (2018). Membangun karakter generasi muda melalui model pembelajaran berbasis kecakapan abad 21. JPK (Jurnal Pancasila Dan Kewarganegaraan), 3(2), 21-27. https:// doi.org/10.24269/jpk.v3.n2.2018.pp21-27

Mukhlis, A., \& Mbelo, F. H. (2019). Analisis Perkembangan Sosial Emosional Anak Usia Dini Pada Permainan Tradisional. Preschool (Jurnal Perkembangan Dan Pendidikan Anak Usia Dini), 1(1). https://doi.org/10.18860/preschool.v1i1.8172

Nata, A. (2018). Pendidikan Islam Di Era Milenial. Conciencia, 18(1), 10-28. https://doi.org/10.19109/conciencia.v18i1.2436

Novrinda, N., Kurniah, N., \& Yulidesni, Y. (2017). Peran Orangtua Dalam Pendidikan Anak Usia Dini Ditinjau Dari Latar Belakang Pendidikan. Jurnal Ilmiah Potensia, 2(1), 39-46. https:// doi.org/10.33369/jip.2.1.39-46

Puspita, A. C., Perbawani, A. A., Adriyanti, N. D., \& Sumarlam, S. (2019). Analisis Bahasa Lisan Pada Anak Keterlambatan Bicara (Speech Delay) Usia 5 Tahun. Lingua, 15(2), 154-160.

https://journal.unnes.ac.id/nju/index.php/lingua/article/view/17405/9508

Ruiyat, S. A., Yufiarti, Y., \& Karnadi, K. (2019). Peningkatan Keterampilan Berbicara dengan Bercerita Menggunakan Komik Elektronik Tematik. Jurnal Obsesi: Jurnal Pendidikan Anak Usia Dini, 3(2), 518-526. https:/ / doi.org/10.31004/obsesi.v3i2.256

Rusadi, B. E., Widiyanto, R., \& Lubis, R. R. (2019). Analisis Learning And Inovation Skills Mahasiswa Pai Melalui Pendekatan Saintifik Dalam Implementasi Keterampilan 
Abad 21. Conciencia, XIX(2), 112-131. https:// doi.org/10.19109/conciencia.v19i2.4323

Salnita, Y. E., Atmazaki, A., \& Abdurrahman, A. (2019). Pemerolehan Bahasa pada Anak Usia 3 Tahun. Jurnal Obsesi: Jurnal Pendidikan Anak Usia Dini, 3(1), 137-145. https:// doi.org/10.31004/obsesi.v3i1.156

Septi, S., \& Eliza, D. (2019). Peningkatkan Kemampuan Interaksi Sosial Anak Melalui Cerita Mamuro Di Taman Kanak-Kanak Istiqomah Lubuk Gadang. JPGI (Jurnal Penelitian Guru Indonesia), 4(2), 92-95. https:/ / doi.org/10.29210/02382jpgi0005

Sofwan, M., \& Habibi, A. (2016). Problematika dunia pendidikan Islam abad 21 dan tantangan pondok pesantren di Jambi. Jurnal Kependidikan: Penelitian Inovasi Pembelajaran, 46(2), 271-280. https://doi.org/10.21831/jk.v46i2.9942

Suardi, I. P., Ramadhan, S., \& Asri, Y. (2019). Pemerolehan Bahasa Pertama pada Anak Usia Dini. Jurnal Obsesi: Jurnal Pendidikan Anak Usia Dini, 3(1), 265-273. https:// doi.org/10.31004/obsesi.v3i1.160

Sumaryanti, L. (2017). Peran Lingkungan terhadap Perkembangan Bahasa Anak. Muaddib: Studi Kependidikan Dan Keislaman, 7(01), 72-89. https:// doi.org/10.24269/muaddib.v7i01.552

Suri, M., \& Nelliraharti, N. (2019). Intensitas Komunikasi Ibu Hamil Terhadap Janin Sebagai Rangsangan Pendengaran dan Perkembangan Otak Dalam Perkenalan Kosakata. Journal of education science, 5(2), 33-37. https:/ / doi.org/10.3314/jes.v5i2.584

Surya, Y. F. (2017). Penggunaan Model Pembelajaran Pendidikan Karakter Abad 21 \pada Anak Usia Dini. Jurnal Obsesi: Jurnal Pendidikan Anak Usia Dini, 1(1), 52-61. https:// doi.org/https:// doi.org/10.31004/obsesi.v1i1.31

Syukur, A., \& Tefanai, M. M. (2017). Meningkatkan Kemampuan Berkomunikasi Anak Melalui Metode Cerita Bergambar pada PAUD Kelompok B. Jurnal PG-PAUD Trunojoyo: Jurnal Pendidikan Dan Pembelajaran Anak Usia Dini, 4(2), 153-163. https:// doi.org/10.21107/pgpaudtrunojoyo.v4i2.3577

Uce, L. (2017). The golden age: Masa efektif merancang kualitas anak. Bunayya: Jurnal Pendidikan Anak, 1(2), 77-92. https://jurnal.arraniry.ac.id/index.php/bunayya/article/view/1322

Ulumudin, I. (2020). Pengembangan Model "Teknik Imitasi” Sebagai Terapi Dasar Untuk Anak Usia Dini Dengan Autisme. Jurnal Ilmiah Visi, 15(1), 41-52. https:// doi.org/https:// doi.org/10.21009/JIV.1501.5

Wright, C., Diener, M. L., \& Kemp, J. L. (2013). Storytelling dramas as a community building activity in an early childhood classroom. Early Childhood Education Journal, 41(3), 197210. https:// doi.org/10.1007/s10643-012-0544-7

Yulsyofriend, Y., Anggraini, V., \& Yeni, I. (2019). Dampak Gadget Terhadap Perkembangan Bahasa Anak Usia Dini. Yaa Bunayya: Jurnal Pendidikan Anak Usia Dini, 3(1), 67-80. https:// doi.org/https:// doi.org/10.24853/yby.3.1.67-80 